\title{
Valores da amplitude de distribuição do tamanho dos eritrócitos (RDW - Red Cell Distribution Width) em equinos da raça puro sangue inglês (PSI) de ambos os sexos de 12 a 24 meses de idade
}

\author{
Red Blood Cell Distribution Width (RDW) in thorougbred horses from 12 to 24 \\ months of age
}

\author{
Mara Regina Stipp Balarin; Joandes Henrique Fonteque²; Cleverson de Souza3;Mere Erika Saito; \\ Aguemi Kohayagawa5; Raimundo Souza Lopes ${ }^{6}$
}

Resumo: O objetivo do presente estudo foi estabelecer valores da amplitude de distribuição do tamanho dos eritrócitos (RDW) em eqüinos clinicamente sadios. Foram utilizadas 90 amostras de sangue de eqüinos da raça Puro Sangue Inglês (PSI), clinicamente sadios de 12 a 24 meses de idade, obtidas por venipunção jugular em tubos à vácuo contendo EDTA $10 \%$. Posteriormente as amostras foram processadas no contador automático de células Cell-Dyn 3500 (Abbott Diagnostic). Os valores médios e o desvios-padrão para o RDW (\%) de machos foi de 26,90 $\pm 1,41$ e para as fêmeas de $26,89 \pm 1,75$. Os resultados demonstram não haver diferenças nos valores de RDW para machos e fêmeas, podendo ser utilizados como referência para ambos os sexos.

Palavras-chave: RDW, equino, PSI, Cell Dyn 3500.

Abstract: The purpose of this study was to establish reference values for red blood cell distribution width (RDW) in health horses. We obtained blood samples through jugular punctured from 90 clinicaly health thorougbred horses between 12 and 24 months of age. Blood was obtained in a Cell-Dyn 3500 (Abbott Diagnostic) cell counter. Mean \pm standart deviation values for RDW in male horses were $26,90 \pm 1,41$, whereas in females values were $26,89 \pm 1,75$. There were no differences in the RDW values between sexes, therefore, our reference values can be used in both males and females. Key words: RDW, equine, PSI, Cell Dyn 3500.

\section{Introdução}

Segundo Roberts (1985), o clássico estudo de Prince-Jones em 1933, foi fundamental para estabelecer a anisocitose como um meio de avaliar a morfologia dos eritrócitos no estado de saúde e na doença. Entretanto, a avaliação microscópica do tamanho do eritrócito é difícil, demorada e subjetiva.

Os contadores eletrônicos de células mostram a distribuição do volume de eritrócitos de $95 \%$ das células de uma amostra na forma de histograma e determinam o coeficiente de variação o qual é denominado de amplitude de distribuição dos eritrócitos (RDW). Este índice reflete a heterogeneidade do tamanho dos eritrócitos, sendo o mais sensível para determinar o grau de anisocitose, segundo Monzon (1986). Weiser et al. (1982), ressalta ainda a importância do RDW para a avaliação das hemácias quando estocadas em bancos de sangue. Com a utilização dos contadores eletrônicos de células, tornou-se possível quantificar a variação do tamanho dos eritrócitos, determinando com maior acurácia o grau de anisocitose.
Na espécie eqüina os eritrócitos são liberados para a circulação periférica quando completamente maduros, sendo difícil a observação de reticulócitos no sangue periférico. Mesmo em situações de intensa eritropoiese, o volume corpuscular médio (VCM), que é o índice mais comumente utilizado para avaliar o grau de anisocitose, apresenta mínimas alterações (SMITH; AGAR, 1976; JEFFCOTT, 1977). Existem dois mecanismos que podem explicar essa resposta em cavalos com anemia: a produção insuficiente de eritropoietina para levar ao aparecimento da reticulocitose e induzir a rápida elevação do volume globular ou o tecido eritropoiético pode não responder de maneira adequada a eritropoietina, como observado em outras espécies. Porém, novos estudos devem ser realizados para evidenciar esse fenômeno (SMITH; AGAR, 1976; JEFFCOTT, 1977).

O RDW é um valor obtido diretamente do analisador por medir o grau de difusão da luz através das partículas entre 360 e $36 \mathrm{fL}$. A difusão da luz é afetada pela forma e tamanho dos eritrócitos. Por esta razão, todas as células são uniformizadas de forma esférica, fazendo

\footnotetext{
${ }^{1}$ Profa. Adj. do Depto de Medicina Veterinária Preventiva, Universidade Estadual de Londrina, UEL, Londrina-PR.

2 Pós-Graduando (Mestrado) do Depto de Clínica Veterinária da UNESP, Botucatu-SP

${ }^{3}$ Pós-Graduando (Mestrado) do Depto de UFSM, Santa Maria-RS

${ }_{4}^{4}$ Pós-Graduando (Mestrado) do Depto de Clínica Veterinária da USP, São Paulo-SP.

${ }^{5}$ Profa. Dr. do Depto de Clínica Veterinária da UNESP, Botucatu-SP.

${ }^{6}$ Prof. Ass. Dr. do Depto de Clínica Veterinária da UNESP, Botucatu-SP.

Redigido como requisito para obtenção do título de Doutor em Medicina Veterinária - FMVZ, UNESP, Botucatu, SP.
} 
com que somente um fator afete a difusão de luz, que é o tamanho das células.

Na medicina humana este índice tem sido bastante utilizado para a avaliação dos diferentes tipos de anemia (ROBERTS et al., 1985; ROMERO-ARTAZA et al., 1999). Roberts et al. (1985), estudando pacientes com diferentes tipos de anemias, observaram que os valores de RDW foram proporcionais a contagem de reticulócitos, com valores mais altos em pacientes com contagem elevada de reticulócitos.

Na medicina veterinária, segundo Weiser (1983) e Easley (1985), os valores de RDW em eqüinos são importantes para identificar o aumento da eritropoiese e avaliar a anemia. Os valores médios obtidos para eqüinos clinicamente sadios foram de $18,5 \%$ e referem a importância de se estabelecer valores para cada laboratório e para cada espécie animal. Radin et al. (1986), induzindo anemias em equinos obervaram aumento significativo nos valores de RDW nos grupos com severa hemorragia e hemólise, obtendo valores máximos de $24,3 \%$ e $26,4 \%$, respectivamente.

O objetivo do presente estudo foi estabelecer valores de RDW em eqüinos Puro Sangue Inglês (PSI), clinicamente sadios, para que possam ser utilizados em estudos comparativos, possibilitando detectar mínimas alterações no tamanho dos eritrócitos.

\section{Material e Métodos}

Foram utilizados 90 eqüinos Puro Sangue Inglês (PSI), clinicamente sadios (45 machos e 45 fêmeas) de 12 a 24 meses de idade, submetidos ao mesmo tipo de manejo alimentar, oriundos da região de Avaré e Boituva no estado de São Paulo. As amostras de sangue foram obtidas por meio de venipunção jugular em tubos á vácuo contendo EDTA à 10\%. Posteriormente as amostras foram processadas em contador eletrônico de células Cell Dyn 3500 (Abbott Diagnostic).

Para a análise estatística dos dados, foi realizado o Teste t de Student $(p<0,05)$ para analisar a variável RDW, a fim de comparar machos e fêmeas.

\section{Resultados e Discussão}

Os valores médios e os desvios-padrão para o RDW (\%) de 45 eqüinos machos e 45 fêmeas da raça Puro Sangue Inglês (PSI), estão representados na Tabela 1 e Figura 1.

Tabela 1 - Valores médios e desvios-padrão do RDW de equinos da raça Puro Sangue Inglês (PSI), machos e fêmeas de 12 a 24 meses de idade, clinicamente sadios.
Figura 1 - Representação gráfica do RDW (\%) de equinos da raça Puro Sangue Inglês (PSI), machos e fêmeas de 12 a 24 meses de idade, clinicamente sadios.

A análise estatística demonstrou não haver diferença significativa $(p<0,05)$ para os valores de RDW $(\%)$ entre eqüinos machos e fêmeas da raça Puro Sangue Inglês (PSI), com idade de 12 a 24 meses.

Comparando-se os valores obtidos com os da literatura, observamos que nossos valores foram superiores aos citados por Easley et al. (1985), que obteve valores médios de RDW de 15,2 a 19,8\% em eqüinos adultos clinicamente sadios de diferentes raças e valores médios de 18,5 a $20,7 \%$ para animais com quadro clínico de perda aguda de sangue.

Valores médios de RDW de 24,3 e $26,4 \%$ foram relatados por Radin et al. (1986), em grupos de eqüinos com severa hemorragia ou hemólise, sendo que nossos valores foram semelhantes a estes, porém para animais clinicamente sadios.

A utilização de animais de diferentes raças no estudo realizado por Easley et al.(1985), pode justificar os valores inferiores aos nossos, onde foram utilizados somente animais da raça Puro Sangue Inglês. Estes resultados demonstram a importância de se estabelecer valores de referência para cada laboratório, espécie e raça.

\section{Conclusão}

Os resultados demonstram não haver diferenças nos valores de RDW (\%) para machos e fêmeas, podendo ser utilizados como referência para ambos os sexos.

\section{Referências}

EASLEY, J.R. Erythrogram and red cell distribution width of equidae with experimentally induced anemia. Am. J. Vet. Res., v.46, n.11, p.2378-84, 1985.

JEFFCOTT, L.B. Comparative clinical haematology. Ed. R. K. Archer., L. B. Jeffcott. Oxford: Blackwell. 1977. p.161214.

MONZON, C.M.; DANIEL BEAVER, B. Evaluation of erythrocyte disorders with mean corpuscular volume (MCV) and red cell distribution width (RDW). Clinical Pediatrics., v.26, n.12, p.632-38, 1986.

RADIN, M.J.; EUBANK, M.C.; WEISER, M.G. Eletronic 
mensurament of erithrocyte volume and volume heterogeneity in horses during erythrocyte regeneration associate with experimental anemias. Vet. Pathol., v.23, n.6, p.656-60, 1986.

ROBERTS, G.T.; EL BADAWI, S.B. Red cell distribution width index in some hematologic diseases. Am. J. Clin. Pathol., v.83, n.2, p.226-6, 1985.

ROMERO-ARTAZA, J. et al. Red cell distribution width (RDW): its use in the characterization of microcytic and hypocromic anemias. Medicina B Aires., v.59, n.1, p.17-22, 1999.
SMITH, J.E.; AGAR, N.S. Studies on erythrocyte metabolism following acute blood loss in the horse. Equine Veterinary Journal., v.8, p.34-7, 1976.

WEISER, M.G. Erithrocyte volume distribution analysis in health dogs, horses, and dairy cattle. Am. J. Vet. Res., v.43, p.163-66, 1982.

WEISER, M.G.; KOCIBA, G.J. Sequential changes in erithrocyte volume distribution and microcytosis associated with iron deficiency in kittens. Vet. Pathol., v.20, p.1-12, 1983. 
